Postgrad. MED. J. (1966), 42, 203.

\title{
FAMILIAL AND MULTIPLE PHAEOCHROMOCYTOMAS
}

\author{
J. J. Brown, M.B., B.Sc., M.R.C.P.
}

J. W. LitchField, B.A., M.B., F.R.C.P.

A. Dickson Wright, M.S., F.R.C.S.

St. Mary's Hospital, London, W.2.

Hyman and Mencher (1943) first reported the occurrence of phaeochromocytomas in more than one member of a single family. A familial incidence of these tumours has since been observed in at least seventeen apparently unrelated families (see Carman and Brashear, 1960 for earlier references; Smits and Huizinga, 1961; Cushman, 1962; Grunstein and Finkelstein, 1962; Tisherman, Gregg and Danowski, 1962; Hagen and Barrows, 1963). Approximately $9 \%$ of all patients with phaeochromocytomas harbour the tumours in both adrenal glands (Graham, 1951; Barbeau, Marc-Aurele, Brouillet, Yitke, Leboeuf, Cartier, Mignault and Genest, 1958; Hume, 1960), but the incidence of bilateral adrenal tumours rises to $24 \%$ in children and to about $50 \%$ in familial cases (Hume, 1960). We report here the occurrence of bilateral adrenal phaeochromocytomas in one patient and of a single adrenal phaeochrome tumour in his sister.

\section{Methods}

Urine was collected for 24 hours into a bottle containing $10 \mathrm{ml}$. of concentrated hydrochloric acid. The quantity of adrenaline and noradrenaline in urine and tumour tissue was estimated using the rat blood pressure preparation and the extraction procedures described by Euler \& Hellner (1951) and Hamilton, Litchfield, Peart \& Sowry (1953). Vanilmandelic acid (VMA) was estimated by the method of Sandler and Ruthven (1961).

\section{Case Reports}

Case No. 1: B. H. Male, aged 44 years. The earlier history of this male patient was reported in previous papers from this hospital (case 3, Barnett, Blacket, Depoorter, Sanderson and Wilson, 1950; case 2, Hamilton, Litchfield, Peart and Sowry, 1953). As a child, he experienced attacks of bradycardia and pallor lasting 2-3 minutes and when he was eleven years old, an electrocardiogram revealed a short $\mathbf{P}-\mathbf{R}$ interval and the changes associated with left bundle branch block (case 7, Wolff, Parkinson and White, 1930). These symptoms subsided, but in 1941, when aged 23, he experienced attacks of epigastric discomfort followed by a slow thumping sensation in the chest, pallor and sometimes a throbbing headache. These symptoms varied in duration from about 2 to 15 minutes and occurred up to twelve times daily. When he was symptom-frees the blood pressure varied from $120 / 86$ to $136 / 90$. $\mathrm{mm}$. Hg.; during the attacks it increased to a maximum of $254 / 154$. A plain X-ras of the abdomen in 1949 (Dr. $E$. Rohas Williams) demonstrated a round mass above the upper pole of the right kidney and in November. of the same year, one of us (A.D.W.) removed the right suprarenal gland containing an encapsulated tumour. The tumour weighed $200 \mathrm{~g}$; brownister granules appeared within the cells after treatmentu with bichromate and histological examination confirmed the diagnosis of phaechromocytoma (Dr॰ R. H. Heptinstall). Pharmacological investigations were not performed at this stage. The patient then remained symptom-free until October, 1957 wher he experienced attacks of palpitation and frequent frontal headaches. These symptoms occurred less often during the next few years, but in Jyly, 1962 he again experienced attacks of slow, regugas forceful palpitation associated with throbbug headache, pallor and a sense of "abdominab emptiness". These lasted about five minutes, 五 and occurred 2-3 times daily. A spontaneous attacls was not observed, but his blood pressure varies between $100 / 60$ and $170 / 100$. Intravenous injection of histamine $(20 \mathrm{mcg}$.) precipitated a typical paroxysn in which the blood pressure increased from $160 / 100$ to $250 / 150$ and ventricular ectopics appeared on the electrocardiogram.

Investigations: The urine was free of sugar and protein. During a twenty-four hour period withoul. an attack, the urine contained $380 \mu \mathrm{g}$ noradrenaline $145 \mu \mathrm{g}$. adrenaline and $14.8 \mathrm{mg}$. V.M.A. Pre-sacra retro-peritoneal air insufflation followed by tomography showed a spherical mass anterior to the upper pole of the left kidney (Dr. David Sutton). At operation on July 12th, 1962 (A.D.W.) the tumou? was found surrounded by a thin rind of adrena? cortex which could not be saved. The tumour was $4 \mathrm{~cm}$. in diameter, weighed $65 \mathrm{~g}$., contained $6.1 \mathrm{mg}$ noradrenaline and $1.0 \mathrm{mg}$. adrenaline per $\mathrm{g}$. wes weight.

Since the opposite adrenal gland had beeps removed previously, the patient was given cortisono by intramuscular injection on the day before, and hydrocortisone intravenously on the day of the operation. Two hours after the operation, the systolic blood pressure suddenly fell to $50 \mathrm{~mm}$. $\mathbf{H g}_{\mathrm{eo}}$ and this was rapidly corrected by a briet noradrenaline infusion. The subsequent course was uneventful and he has remained symptom-free while continuing replacement therapy with cortisone $(37.50$ mg. daily) and $9 \alpha$-fluorohydrocortisone $(0.1 \mathrm{mg}$ ? daily). In September, 1964 his blood pressure was 140/80 mm. Hg. 
Case no. 2: E.H. Female, aged 48 years. This unmarried sister of case 1 was well until 1960 when she first noticed attacks of weakness, tremor, occipital headache and nausea without vomiting. Slight bradycardia and blurring of near vision occurred in some attacks. She had experienced many minor attacks lasting 10-15 minutes and seven severe paroxysms which persisted for about an hour. Small attacks were sometimes provoked by twisting the trunk to the right.

Examination showed a rather thin, alert woman whose blood pressure was 145/90 and pulse rate regular at 70 per min. Spontaneous attacks did not occur while the patient was in hospital but intravenous injection of histamine $(20 \mathrm{mcg}$. $)$ precipitated a typical paroxysm during which the pulse became irregular at a rate of 130 per min., and the blood pressure increased from $145 / 90$ to $225 / 150$.

Investigations. There was no sugar or protein in the urine and the blood sugar, haemoglobin, plasma electrolytes, chest X-ray and intravenous pyelogram were normal. During a twenty-four hour period without an attack, the urine contained $100 \mu \mathrm{g}$ noradrenaline, $50 \mu \mathrm{g}$ of adrenaline and $12.6 \mathrm{mg}$. of VMA. These results are discussed in a separate communication (Brown, Ruthven and Sandler, 1966). $25 \mu \mathrm{g}$. of noradrenaline and $45 \mu \mathrm{g}$. of adrenaline were excreted in four hours after the attack precipitated by histamine. Pre-sacral retroperitoneal pneumography followed by tomography demonstrated a spherical mass anterior to the upper pole of the left kidney. (Dr. E. Rohan Williams). At operation in March, 1962 the tumour was removed without the rest of the gland to which it was attached by a thin bridge of tissue. The tumour weighed $30 \mathrm{~g}$., and contained $20 \mu \mathrm{g}$. noradrenaline and $50 \mu \mathrm{g}$. adrenaline per g., wet weight. The post-operative course was uneventful and 19 days later a twentyfour hour urine specimen contained $60 \mu \mathrm{g}$. noradrenaline, $20 \mu \mathrm{g}$. adrenaline and $4.5 \mu \mathrm{g}$. VMA. (i.e., all within the normal range). Attacks have not occurred since the operation.

\section{Discussion}

In 1957, the world literature contained records of 626 patients with phaeochromocytoma (Barbeau, 1957). The present report brings the total number of familial patients with phaeochromocytomas to at least fifty and the affected kindred to eighteen. A family history of these tumours, therefore, occurs in $7-8 \%$ of the published series, but the true incidence is probably lower since familial cases are more likely to be recorded. The incidence of phaeochromocytomas is increased in patients with neurofibromatosis and possibly in cases with other hereditary neurocutaneous syndromes (Glushien, Mansuy and Littman, 1953; Chapman, Kemp and Taliaferro, 1959), but evidence of these diseases were not found in our cases or in their relatives. Smits and Huizinga (1961) found four patients with phaeochromocytomatas and ten other cases with a history of characteristic attacks, in a single Dutch family. In seven of the seventeen published family pedigrees, phaeochrome tumours occurred in a parent and sibling and there was a strong clinical suspicion of these tumours in the father or mother of five other cases. The mother of the two cases reported here has persistent hypertension but she denied any paroxysmal symptoms. Phaeochromocytomas may present in this way (Thorn, Hindle and Sandmeyer, 1944; Goldenberg, Aranow, Smith and Faber, 1950; de Graeff and Horak, 1963), but the diagnosis seems unlikely in this patient since the excretion of catechol amines was normal (Table 1). Although the urinary catechol amines may be normal between (Pitkanen, 1956; Thompson and Trounce, 1958) or during (Litchfield and Peart, 1956) paroxysmal hypertensive attacks, as far as we are aware increased excretion has always been found in patients with a phaeochromocytoma and persistent hypertension. The father of this family has carcinoma of the prostate gland. He denied symptoms suggestive of phaeochromocytoma and his blood pressure was $170 / 100 \mathrm{~mm}$. Hg. Although carcinoma of the thyroid gland is more common in patients with phaeochromocytoma (Sipple, 1961), we are not aware of a similar relationship between adrenal and prostatic tumours. The two children of B.H. are symptom-free and the excretion of catechol amines and VMA was normal in both cases (Table 1). However, the average age at the time of diagnosis in familial cases is twenty-six years. The surprisingly high incidence of familial phaeochromocytomas has led to the suggestion that this is a hereditary trait with a dominant autosomal mode of inheritance (Carman and Brashear, 1960; Smits and Huizinga, 1961; Cushman, 1962). If this is valid, incomplete penetrance of the gene might explain the absence of tumours from some generations, while truly sporadic cases could be caused by mutation. In this connection, it is noteworthy that neurofibromatosis, which is often associated with a phaeochromocytoma, appears to arise by mutation more frequently than most hereditary traits (Crowe, Schull and Neel, 1956).

Although bilateral adrenal phaeochromocytomas occur in approximately $50 \%$ of patients with a family history of this disease (Hume, 1960), the long symptom-free period after the first operation in patient B.H. suggests that the second tumour was a more recent development. However, the frequency of attacks varies and a spontaneous remission 
TABLE 1.

URINARY EXCRETION OF NORADRENALINE, AdRENALINE AND VMA

lasting five years was reported by Maddox and Rothwell (1958). Following the removal of a sole phaeochromocytoma, the urinary excretion of catechol amines (Euler, Gemzell, Strom and Westman, 1955; Peart, 1963) and of VMA (Sandler and Ruthven, 1961; Moolenaar, 1963) returns to normal after a delay which may last several weeks. When the excretion of these substances remains elevated for longer periods post-operatively, the presence of another phaeochromocytoma or of metastases from the first tumour should be suspected (Davis, Peart and van't Hoff, 1955). The excision of the first tumour in B.H. preceded the development of the appropriate pharmacological and biochemical techniques, but the normal results after the second operation in this patient and following the removal of one tumour from E.H. suggest that all phaeochrome tumour tissue has been removed.

We wish to thank Drs. M. Sandler and C. R. J. Ruthven for the VMA estimations.

\section{REFERENCES}

Barbeau, A. (1957): Le Phaeochromocytome: une Revue Generale du Sujet, Un. méd. Can., 86, 1045.

Barbeau, A., Marc-Aurele, J. Brouillet, J., YitKe, B., Leboeuf, G. Cartier, P., Mignault,, G. and GENEST, J. (1958): Le "Phaeochromocytome Bilateral: Presentation d'un Cas et Revue de la Litterature, Un. méd. Can., 87, 165.

Barnett, A. J., Blacket, R. B., Depoorter, A. E., SANDERSON, P. H. and WILSON, G. M. (1950): The Action of Noradrenaline in $M a n$ and its Relation to Phaeochromocytoma and Hypertension, Clin. Sci., 9, 151.

Brown, J. J., RUTHVEN, C. R. J. and SANDler, M. (1966): In preparation.

Carman, C. T. and Brashear, R. E. (1960): Phaemochromocytoma as an Inherited Abnormality, New Engl. J. med., 263, 419.

Chapman, R. C., KeMP, V. E. and Taliaferro, $I$. (1959): Phaeochromocytoma Associated with Multiple Neurofibromatosis and Intracranial
Haemangioma, Amer. J. med., 26, 883.

Crowe, F. W., Schull, W. J. and NeEl, J. V. (1956): A Clinical, Pathological and Genetic oo Study of Multiple Neurofibromatosis, p. 168. i Springfield, Illinois: Charles C. Thomas.

Cushman, P. (1962): Familial Endocrine Tumours. Report of Two Unrelated Kindred Affected with $\frac{\text { O }}{2}$ Phaeochromocytomas, One Also with Multiple Thyroid Carcinoma, Amer. J. med., 32, 352.

Davis, P., Peart, W. S. and van't Hoff, W. (1955): Malignant Phaeochromocytoma with Functioning $\frac{\rho}{S}$ Metastases, Lancet, ii, 274.

EULER, U. S. VON and HELLNER, S. (1951尺 $\vec{\varnothing}$ Excretion of Noradrenaline, Adrenaline apd Hydroxytyramine in Urine, Acta physiol. scan 22, 161.

Euler, U. S. von, Gemzell, C. A., Strom, G. and $W$ ESTMAN, A. (1955): Report of a Case of Phaeochromocytoma, with Special Regard to Pre-operative Diagnostic Problems, Acta. med. scand., 153, 127.

Glushien, A. S., MansuY, M. $M$. and Littman, $\overrightarrow{\vec{\partial}}$ D. S. (1953): Phaeochromocytoma, its Relationship 3 to the Neurocutaneous Syndromes, Amer. J. med., 14, 318 .

Goldenberg, M., ARANOW, H. Jr., SMith, A. A. and FABER, M. (1950): Phaeochromocytoma and Essential Hypertensive Disease, Arch. intern. med., 86, 823.

GRAHAM, J. B. (1951): Phaeochromocytoma and Hypertension: an Analysis of 207 Cases, Int. Abstr. Surg., 92, 105.

GraefF, J. de and Horak, B. J. V. (1963): The Incidence of Phaeochromocytoma in the Nether- $\frac{\text { ? }}{?}$ lands. In Boerhaave Course on Hypertension, Ed.

J. de Graeff. p. 320-327. Leyden University,
GrunsteIN, I., and FINKELSTEIN, W. E. (1962): Amer. J. Obstet. Gynaec., 83, 508.

HAGEN, K. O. voN and BARRows, H. S. (1963): Familial Phaeochromocytoma with Epyndymoma $N$ of the Spinal Cord. Case Report and Review of $\mathrm{N}$ the Literature, J. Neurosurg., 20, 600.

hamilton, M., Litchfield, J. W., Peart, W. S. and SowrY, G. S. C. (1953): Phaeochromocytoma, Brit. Heart. J., 15, 241.

HUME, D. M. (1960): Phaeochromocytoma in the $\stackrel{0}{+}$ Adult and in the Ohild, Amer. J. Surg., 99, 458.

HymaN, A. and MENCHER, W. H. (1943): Phaeochromocytoma of the Adrenal Gland, J. Urol. $\frac{\vec{D}}{\mathrm{D}}$ (Baltimore), 49, 755. 
Litchfield, J. W. and Peart, W. S. (1956): Phaeochromocytoma with Normal Excretion of Adrenaline and Noradrenaline, Lancet. ii, 1283.

MadDOX, K. and Rothwell, F. L. (1958): Phaeochromocytoma of Long Duration, Med. J. Austr., 2, 123.

MoolenaAR, A. J. (1963): A Rapid Method for the Quantitative Determination of Vanillylmandelic Acid in the Urine. In Boerhaave Course on Hypertension, p. 310-315. Ed. J. de Graeff. Leyden University.

Peart, W. S. (1963): Discussion in Boerhaave Course on Hypertension, p. 318. Ed. J. de Graeff. Leyden University.

Pitkanen, E. (1956): Studies on the Determination and Excretion of Adrenaline and Noradrenaline in Urine, Acta physiol. scand. Supp. (129), 38, 5.

SANDler, M. and RuthVEN, C. R. J. (1961): The Estimation of 4-Hydroxy-3-methoxymandelic Acid in Urine, Biochem. J., 80, 78.
Sipple, J. H. (1961): The Association of Phacochromocytoma with Carcinoma of the Thyroid Gland, Amer. J. med., 31, 163.

Smits, M. and HuIzinga, J. (1961): Familial Occurrence of Phaeochromocytoma, Acta gent., 11, 137.

Thompson, R. H. S. and Trounce, J. R. (1958): Urinary Excretion of Catechol Amines in Phaeochromocytoma and other Abnormal States, Guy's Hosp. Rep., 107, 475.

ThorN, G. W., Hindle, J. A. and SANDMEYer, J. A. (1944): Phaeochromocytoma of the Adrenal Associated with Persistent Hypertension: Case Report, Ann. intern. med., 21, 122.

Tisherman, S. E., GregG, F. J. and Danowski, T. S. (1962): Familial Phaeochromocytoma, J. Amer. med. Ass., 182, 152.

WolfF, L., Parkinson, J. and White, P. D. (1930): Bundle-branch Block with Short P-R interval in Healthy Young People Prone to Paroxysmal Tachycardia, Amer. Heart J. 5, 685. 